\section{Onion Variety Response to Iris Yellow Spot Virus}

\author{
Clinton C. Shock ${ }^{1,4}$, Erik Feibert ${ }^{1}$, Lynn Jensen ${ }^{2}$, \\ S. Krishna Mohan ${ }^{3}$, and Lamont D. Saunders ${ }^{1}$
}

Additional index words. Allium cepa, market grade, bulb size, single center, neck rot, plate rot, bolting, crop maturity, Treasure Valley

\begin{abstract}
Summary. Onion (Allium cepa) varieties for commercial production in eastern
Oregon and southwestern Idaho are evaluated annually in replicated trials conducted at the Malheur Experiment Station, Oregon State University, near Ontario, Oregon. Characteristics evaluated include bulb yield, market grade, and the frequency of single centers. After the emergence of iris yellow spot virus (IYSV) as a threat to commercial onion production in the early $2000 \mathrm{~s}$, onion varieties at the Malheur Experiment Station have been evaluated for virus symptoms since 2004. Varieties showed differences in the severity of IYSV symptoms each year. Symptom severity increased over the years from 2004 to 2006, and variety virus ratings showed a strong negative correlation of severity with yield in 2005 and 2006. Marketable yield after 3 months of storage averaged 781,534 , and $551 \mathrm{cwt} /$ acre in 2004, 2005, and 2006, respectively. Averaging over varieties, yield of bulbs larger than 4 inches in diameter was $438 \mathrm{cwt} / \mathrm{acre}, 56 \mathrm{cwt} / \mathrm{acre}$, and $76 \mathrm{cwt} / \mathrm{acre}$, and the average virus severity ratings were $1.1,1.3$, and 2.7 in 2004, 2005, and 2006, respectively. A few varieties showed a combination of high yield, large bulb size, low incidence of virus symptoms, and a predominance of single-centered bulbs. With the prevalence of IYSV, variety tolerance to IYSV has become an important production factor in the Treasure Valley.
\end{abstract}

$\mathrm{E}$ ach year, onion is produced on about 20,000 acres in eastern Oregon and southwestern Idaho, with a total market value of about $\$ 47, \$ 92$, and $\$ 108$ million in 2004, 2005, and 2006, respectively (U.S. Department of Agriculture, 2007). Onions are mostly long-day varieties and are marketed starting in August from the field and continuing to April from storage (Shock et al., 2000 ). The onion production area is within a radius of 30 miles of Ontario, Oregon, in the Snake River plain and along the tributaries of the Snake River, a region frequently referred to as the Treasure Valley. This region is characterized by high onion bulb yields and production of a large proportion of large-diameter bulbs.

Funds for this study were provided in part by the Oregon State University Experiment Station, Project 304. Financial support from the Idaho EasternOregon Onion Research Committee, the Malheur County Onion Growers, and onion seed companies is gratefully acknowledged.

${ }^{1}$ Malheur Experiment Station, Oregon State University, 595 Onion Avenue, Ontario, OR 97914

${ }^{2}$ Malheur County Extension, Oregon State University, 710 SW 5th Avenue, Ontario, OR 97914

${ }^{3}$ Southwest Idaho Research and Extension Center, 29603 U of I Lane, Parma, ID 83660-6699

${ }^{4}$ Corresponding author. E-mail: clinton.shock@ oregonstate.edu.
Seed companies are continually developing new varieties. These varieties need to be evaluated across years and locations to determine which varieties are best for any particular location. Since 1972, established varieties and new onion lines for commercial production in the Treasure Valley have been evaluated in replicated trials conducted at the Malheur Experiment Station near Ontario, Oregon. The trials are conducted using standard commercial production practices so that results will be meaningful to growers. Characteristics that have been evaluated in these trials include bulb yield and size, maturity rating, potential for bolting, and susceptibility to neck rot (Botrytis allii and Botrytis aclada) and plate rot
(Fusarium oxysporum f. sp. cepae) diseases (Shock et al., 2000). Starting in 2000 , two additional variety characteristics were evaluated: super colossal size bulbs $(>41 / 4$ inches diameter) and single-centered bulbs (Shock et al., 2005a).

An onion bulb is single-centered when all concentric rings in the bulb end in one center. Single centers are an important characteristic for the food industry. Onion ring manufacturing efficiency is reduced when onions have multiple centers. Onion ring manufacturers have a target of $85 \%$ of the bulbs being single-centered or having a multiple center no larger than 1.5 inches diameter ("functionally single-centered"). Single-centered bulbs are, to some extent, a variety attribute (Shock et al., 2005a) and this is a heritable onion trait that allows for the development of varieties with a high degree of single centers (Cramer, 2006; Gamie et al., 1995; Wall et al., 1996;).

Iris yellow spot virus (IYSV) causes seed stalk and leaf tissue necrosis and has recently been recognized as a serious disease of onion (Gent et al., 2006). IYSV was first found in the Treasure Valley infecting onion seed crops in 1989 (Mohan and Moyer, 2004) and is now known to occur in many onion-producing areas around the world. Onion plants infected with the virus can progressively lose leaf area, resulting in reduced yield and reduced bulb size. The virus is transmitted by onion thrips (Thrips tabaci) (Kritzman et al., 2001; Nagata and Almeida, 1999). The incidence of IYSV might be increased by the inadequate control of onion thrips, which have become increasingly resistant to pyrethroid and organophosphate insecticides (Allen et al., 2005). The disease

\begin{tabular}{llll}
\hline $\begin{array}{l}\text { Units } \\
\begin{array}{l}\text { To convert U.S. to SI, } \\
\text { multiply by }\end{array}\end{array}$ & U.S unit & SI unit & $\begin{array}{l}\text { To convert SI to U.S., } \\
\text { multiply by }\end{array}$ \\
\hline 0.4047 & acre(s) & $\mathrm{ha}$ & $2.471 \mathrm{l}$ \\
1 & $\mathrm{cbar}$ & $\mathrm{kPa}$ & 1 \\
112.0851 & $\mathrm{cwt} / \mathrm{acre}$ & $\mathrm{kg} \cdot \mathrm{ha}^{-1}$ & 0.0089 \\
0.3048 & $\mathrm{ft}$ & $\mathrm{m}$ & 3.2808 \\
9.3540 & gal $/ \mathrm{acre}$ & $\mathrm{L} \cdot \mathrm{ha}^{-1}$ & 0.1069 \\
2.54 & inch $(\mathrm{es})$ & $\mathrm{cm}$ & 0.3937 \\
0.4536 & $\mathrm{lb}$ & $\mathrm{kg}$ & 2.2046 \\
1.1209 & $\mathrm{lb} / \mathrm{acre}$ & $\mathrm{kg} \cdot \mathrm{ha}^{-1}$ & 0.8922 \\
1.6093 & mile(s) & $\mathrm{km}$ & 0.6214 \\
$\left({ }^{\circ} \mathrm{F}-32\right) \div 1.8$ & ${ }^{\circ} \mathrm{F}$ & ${ }^{\circ} \mathrm{C}$ & $\left(1.8 \times{ }^{\circ} \mathrm{C}\right)+32$ \\
& & &
\end{tabular}


was first observed in commercial bulb onion fields in the Treasure Valley in the early 2000s. IYSV was confirmed in symptomatic onion leaves in these fields using double antibody sandwich enzyme-linked immunosorbant assay following the protocol provided by Agdia (Elkhart, IN). With the spread of the virus to bulb crops in the Treasure Valley in the early 2000s, there arose the necessity of evaluating varieties for virus symptoms. Symptoms of the virus at the Malheur Experiment Station became apparent in 2004. This article presents performance of varieties and examines possible relationships between IYSV symptoms and bulb yield and size for varieties of yellow onions in trials conducted at the Malheur Experiment Station in 2004, 2005, and 2006. In this article, established varieties and experimental lines on the verge of commercial release are referred to as varieties.

\section{Materials and methods}

Onion variety trials were conducted at the Malheur Experiment Station near Ontario, Oregon, on Owyhee silt loam (coarse-silty, mixed, mesic Xerollic Camborthid) in 2004 and 2006, and on Greenleaf silt loam (fine-silty, mixed, mesic Xerollic Haplargid) in 2005. The fields each year had previously been planted to wheat (Triticum aestivum), and had $2 \%, 2.4 \%$, and $1.5 \%$ organic matter and a water $\mathrm{pH}$ of 7.3 , 7.7 , and 7.4 in 2004,2005 , and 2006 , respectively. The wheat stubble was shredded and the fields were deep-chiseled, disked, irrigated, moldboard-plowed, roller-harrowed, and bedded in the fall. Each year, before fall plowing, fertilizer was broadcast based on soil analyses and according to extension guidelines (Sullivan et al., 2001). At bedding, the field was fumigated with $20 \mathrm{gal} /$ acre of Telone C-17 (77.9\% 1,3dichloropropene $+16.5 \%$ chloropicrin; Dow AgroSciences, Indianapolis) and left until spring without further tillage.

Beds were harrowed down the day before planting. Seeds were planted on 19 Mar. 2004, 15 Mar. 2005, and 23 Mar. 2006. The seed was planted in double-rows on 22 inch beds. The double rows were spaced 3 inches apart. The seeding rate was 9 seeds/ft of single row for subsequent thinning. Seed was planted with a customized planter using John Deere Flexi Planter (John Deere Co., Moline, IL) units equipped with disc openers. For all years, each variety was planted in plots four double rows wide (88 inches) and $27 \mathrm{ft}$ long with five replications. The experimental design was a randomized complete block.

Immediately after seeding, chlorpyrifos at $2 \mathrm{oz} /$ acre was broadcast, the soil surface was rolled, and the first furrow irrigation was applied to supply moisture for seed germination. In late May, 4-ft-wide alleys were cut between plots, leaving plots $23 \mathrm{ft}$ long. Onion seedlings were hand thinned to a plant spacing of 6 inches between individual onion plants within the single rows of the double rows $(95,000$ plants/acre). Each year, the fields were sidedressed with a total of $200 \mathrm{lb} /$ acre nitrogen $(\mathrm{N})$ as urea. The total amount of $\mathrm{N}$ was split into two sidedressings of $100 \mathrm{lb} /$ acre each, applied in late May and mid to late June. Other nutrients were applied as needed based on root tissue analyses.

Weeds were controlled with cultivation and low-rate herbicide applications as needed until early July, when onion foliage growth precluded further tractor traffic. Herbicides included bromoxynil, oxyfluorfen, sethoxydim, and pendimethalin (Peachey, 2007). Thrips were controlled with aerial applications of cyhalothrin, methomyl, oxydemeton-methyl, zeta-cypermethrin, and formetanate hydrochloride from June through August (McGrath et al., 2007). Four aerial applications for thrips control were made in 2004, nine were made in 2005, and seven were made in 2006.

Trials were furrow irrigated when the soil water tension at an 8inch soil depth reached 25 cbar (Shock et al., 1998). Soil water tension was monitored by six granular matrix sensors (model 200SS; Watermark Soil Moisture Sensors; Irrometer Co., Riverside, CA) installed in mid-June below the onion row at an 8-inch depth (Shock, 2003; Shock et al., 2005b). Sensors were automatically read three times a day with an AM-400 m (Mike Hansen Co., East Wenatchee, WA) as described previously (Shock et al., 2002,
$2005 b)$. The last irrigation of the season was in late August.

Each plot was rated subjectively for the severity of IYSV symptoms on 11 Aug. 2004, 19 Aug. 2005, and 22 Aug. 2006. A single rating was given for each plot on a scale of 0 to 5 of increasing severity of symptoms, where $0=$ no symptoms, $1=1 \%$ to $25 \%$ of foliage diseased, $2=26 \%$ to $50 \%$ of foliage diseased, $3=51 \%$ to $75 \%$ of foliage diseased, $4=76 \%$ to $99 \%$ of foliage diseased, and $5=100 \%$ of foliage diseased. Each plot was also rated for maturity immediately after the IYSV rating. Bulb maturity ratings were the average of visual estimates of percentage of dry leaf material and percentage of bulbs with necks collapsed and leaves on the ground. Presence of the virus was confirmed by testing three symptomatic leaf samples using the double antibody sandwich-enzyme-linked immunoabsorbant assay on 22 Aug. 2006.

In early September, bulbs from one of the border rows in each plot were rated for single centers. Twentyfive consecutive onions ranging in diameter from $3 \frac{1}{2} 2$ to $4^{1 / 4} 4$ inches were rated. The onions were cut equatorially through the bulb middle and, if multiple-centered, the long axis of the i.d. of the first single ring was measured. These multiple-centered onions were ranked according to the diameter of the first single ring: small had diameters $<1 \frac{1}{1} 2$ inch, medium had diameters from $1^{1 / 2}$ to $2^{1 / 4}$ inches, and large had diameters $>21 / 4$ inches. Onions were considered functionally single-centered for processing if they were single-centered or a small double.

Onion roots were under cut in September and the bulbs were left to field-dry for 7 to $10 \mathrm{~d}$. Onions from the middle two rows of each plot were hand-topped in late September and placed into burlap bags. The bags were placed into wooden bins $(4 \times 4$ $\times 5 \mathrm{ft}$ ), and the bins were moved into a storage facility with circulating ventilation. The storage facility was maintained as close to $34{ }^{\circ} \mathrm{F}$ and $70 \%$ relative humidity as possible using outdoor ambient air to cool the storage.

Onion varieties were evaluated based on bulb grade out of storage the following January, $\approx 3$ months after harvest. During grading, bulbs 
Table 1. Marketable yield by bulb diameter size for 'Vaquero' onion over 7 years.

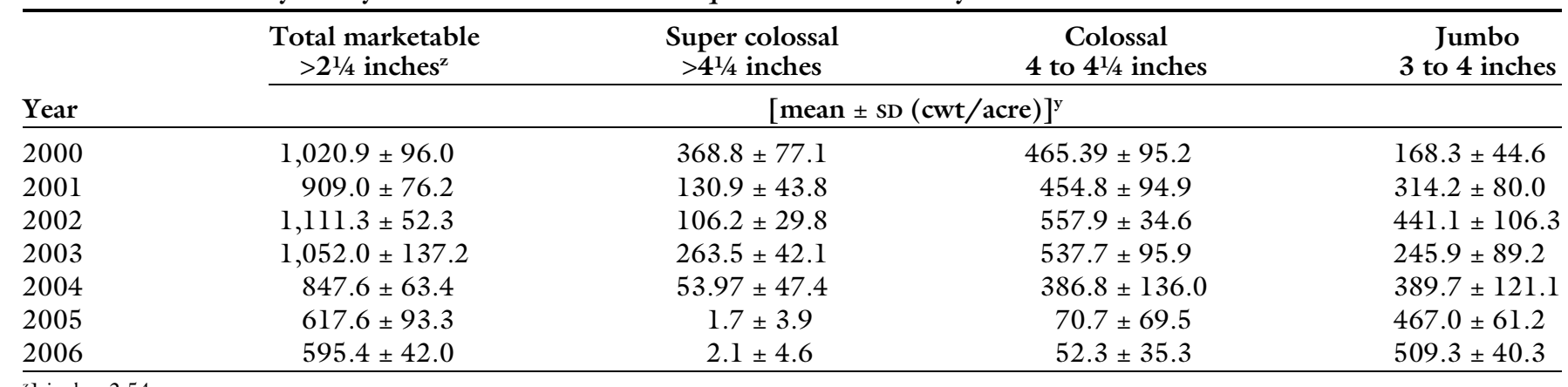

${ }^{\mathrm{z}} 1$ inch $=2.54 \mathrm{~cm}$.

${ }^{\mathrm{y}} \mathrm{l} \mathrm{cwt} / \mathrm{acre}=112.085 \mathrm{l} \mathrm{kg} \cdot \mathrm{ha}^{-1}$.

Table 2. Bulb yield, single center rating, and iris yellow spot virus (IYSV) rating for onion varieties evaluated in 2004.

Varieties are ranked by IYSV rating.

\begin{tabular}{|c|c|c|c|c|c|c|c|c|}
\hline \multirow[b]{2}{*}{ Variety } & \multirow[b]{2}{*}{ Source ${ }^{\mathrm{z}}$} & \multicolumn{4}{|c|}{ Marketable yield by bulb diameter (cwt/acre) $)^{\mathrm{y}}$} & \multirow[b]{2}{*}{$\begin{array}{l}\text { Single } \\
\text { center }\end{array}$} & \multirow[b]{2}{*}{$\begin{array}{c}\begin{array}{c}\text { Functional } \\
\text { single center }\end{array} \\
(\%)\end{array}$} & \multirow[b]{2}{*}{$\begin{array}{l}\text { IYSV rating } \\
(0-5 \text { scale })^{\mathrm{v}}\end{array}$} \\
\hline & & $\begin{array}{c}\text { Total } \\
>21 / 4 \\
\text { inches }^{x} \\
\end{array}$ & $\begin{array}{c}\text { Super colossal } \\
>4^{1 / 4} \\
\text { inches }\end{array}$ & $\begin{array}{l}\text { Colossal } \\
4 \text { to } 4^{1 / 4} \\
\text { inches }\end{array}$ & $\begin{array}{l}\text { Jumbo } \\
3 \text { to } 4 \\
\text { inches }\end{array}$ & & & \\
\hline $\mathrm{T}-433$ & A. Takii & 821.3 & 167.9 & 421.7 & 216.4 & 8.0 & 28.0 & 0.9 \\
\hline PX 5299 & Seminis & 895.5 & 227.9 & 467.3 & 193.8 & 22.7 & 61.3 & 0.9 \\
\hline Delgado & Bejo & 644.8 & 9.8 & 182.1 & 443.1 & 4.0 & 43.3 & 0.9 \\
\hline BGS $196 \mathrm{Fl}$ & Bejo & 761.8 & 43.1 & 288.1 & 411.6 & 26.0 & 69.3 & 0.9 \\
\hline PX 2599 & Seminis & 900.7 & 244.2 & 464.7 & 182.3 & 26.7 & 63.3 & 0.9 \\
\hline Sabroso & Nunhems & 560.4 & 1.8 & 60.0 & 474.4 & 74.4 & 93.6 & 0.9 \\
\hline Outlaw & Global Gen. & 638.9 & 10.7 & 140.0 & 464.9 & 47.3 & 81.3 & 1.0 \\
\hline Bandolero & Nunhems & 626.8 & 3.7 & 52.2 & 536.4 & 80.8 & 93.6 & 1.0 \\
\hline Montero & Nunhems & 798.9 & 45.2 & 337.3 & 398.2 & 66.9 & 93.7 & 1.0 \\
\hline Sweet Perfection & Crookham & 969.8 & 169.9 & 439.9 & 339.9 & 41.3 & 56.7 & 1.0 \\
\hline Varsity & Global Gen. & 616.0 & 30.3 & 195.5 & 378.6 & 56.0 & 88.0 & 1.0 \\
\hline SVR 5819 & Seminis & 895.3 & 130.0 & 440.9 & 309.5 & 42.0 & 81.3 & 1.0 \\
\hline Daytona & Bejo & 624.5 & 8.3 & 139.5 & 444.3 & 5.3 & 20.7 & 1.1 \\
\hline Pandero & Nunhems & 884.5 & 132.7 & 428.6 & 310.6 & 38.0 & 64.0 & 1.1 \\
\hline Tequila & D. Palmer & 831.3 & 190.5 & 403.2 & 229.0 & 40.0 & 58.7 & 1.1 \\
\hline Ranchero & Nunhems & $1,025.7$ & 205.8 & 500.8 & 302.6 & 36.8 & 64.0 & 1.2 \\
\hline Harvest Moon & Dorsing & 786.2 & 220.8 & 350.6 & 206.2 & 18.7 & 36.7 & 1.2 \\
\hline Ringleader & Global Gen. & 803.0 & 130.3 & 418.0 & 237.1 & 82.0 & 94.7 & 1.2 \\
\hline OLYS97-27 & Crookham & 835.6 & 144.7 & 397.9 & 272.7 & 24.0 & 38.7 & 1.3 \\
\hline Avg & & 779.9 & 108.0 & 328.3 & 327.0 & 36.7 & 61.3 & 1.1 \\
\hline Tukey's HsD (0.05 & & 145.1 & 72.0 & 103.3 & 116.1 & 16.1 & 23.7 & 0.7 \\
\hline
\end{tabular}


Table 3. Bulb yield, single center rating, and iris yellow spot virus (IYSV) rating for onion varieties evaluated in 2005. Varieties are ranked by IYSV rating.

\begin{tabular}{|c|c|c|c|c|c|c|c|c|}
\hline \multirow[b]{2}{*}{ Variety } & \multirow[b]{2}{*}{ Source ${ }^{\mathrm{z}}$} & \multicolumn{4}{|c|}{ Marketable yield by bulb diameter $(\mathrm{cwt} / \mathrm{acre})^{\mathrm{y}}$} & \multirow[b]{2}{*}{$\begin{array}{l}\text { Single } \\
\text { center }\end{array}$} & \multirow[b]{2}{*}{$\begin{array}{c}\begin{array}{c}\text { Functional } \\
\text { single center }\end{array} \\
(\%)\end{array}$} & \multirow[b]{2}{*}{$\begin{array}{l}\text { IYSV rating } \\
(0-5 \text { scale })^{v}\end{array}$} \\
\hline & & $\begin{array}{c}\text { Total } \\
>21 / 4 \\
\text { inches }^{x} \\
\end{array}$ & $\begin{array}{c}\text { Super colossal } \\
>4^{1 / 4} \\
\text { inches } \\
\end{array}$ & $\begin{array}{l}\text { Colossal } \\
4 \text { to } 4^{1 / 4} \\
\text { inches } \\
\end{array}$ & $\begin{array}{l}\text { Jumbo } \\
3 \text { to } 4 \\
\text { inches }\end{array}$ & & & \\
\hline Joaquin & Nunhems & 771.9 & 14.3 & 164.6 & 538.0 & 74.4 & 95.2 & 0.7 \\
\hline $\mathrm{T}-433$ & A. Takii & 633.9 & 0.0 & 47.4 & 490.9 & 8.8 & 34.4 & 0.9 \\
\hline Harmony & Crookham & 639.7 & 8.8 & 118.2 & 450.6 & 44.0 & 75.2 & 1 \\
\hline Maverick & Global Gen. & 615.9 & 9.2 & 105.6 & 431.8 & 62.4 & 80.0 & 1 \\
\hline Charismatic & Seminis & 668.7 & 21.0 & 144.8 & 431.7 & 27.2 & 72.8 & 1 \\
\hline Affirmed & Seminis & 631.5 & 1.2 & 85.3 & 492.5 & 64.9 & 93.1 & 1.1 \\
\hline Ranchero & Nunhems & 645.8 & 3.4 & 86.2 & 476.2 & 48.8 & 83.2 & 1.1 \\
\hline Vaquero & Nunhems & 617.6 & 1.7 & 70.7 & 467.0 & 64.0 & 84.8 & 1.1 \\
\hline Granero & Nunhems & 567.8 & 0.0 & 26.0 & 441.9 & 48.5 & 84.1 & 1.2 \\
\hline Pandero & Nunhems & 562.4 & 1.5 & 36.9 & 443.5 & 49.6 & 80.8 & 1.2 \\
\hline Arcero & Nunhems & 677.5 & 0.0 & 72.8 & 530.4 & 74.4 & 91.2 & 1.2 \\
\hline King George & Rispens & 287.7 & 0.0 & 0.0 & 157.6 & 33.6 & 67.2 & 1.4 \\
\hline Monarchos & Seminis & 545.6 & 0.0 & 19.8 & 441.2 & 80.1 & 96.1 & 1.4 \\
\hline Montero & Nunhems & 520.2 & 0.0 & 18.5 & 385.9 & 56.8 & 91.2 & 1.5 \\
\hline Outlaw & Global Gen. & 331.3 & 1.2 & 10.4 & 225.1 & 54.4 & 81.6 & 1.6 \\
\hline Calibra & Bejo & 374.7 & 0.0 & 0.8 & 246.6 & 4.0 & 34.4 & 1.7 \\
\hline Varsity & Global Gen. & 300.8 & 0.0 & 11.8 & 184.2 & 52.0 & 80.8 & 1.7 \\
\hline Sabroso & Nunhems & 369.9 & 0.0 & 3.4 & 199.4 & 49.6 & 96.0 & 1.7 \\
\hline Talon & Bejo & 263.7 & 0.0 & 0.0 & 128.9 & 60.0 & 88.8 & 1.9 \\
\hline
\end{tabular}

${ }^{2}$ American Takii, Inc., Salinas, CA; Bejo Seeds, Inc., Oceano, CA; Crookham Co., Caldwell ID; D. Palmer Seed Co., Yuma, AZ; Global Genetics, Payette, ID, Rispens Seeds, Inc., Beecher, IL; Seminis, Inc., Oxnard, CA; Nunhems, Parma, ID.

${ }^{\mathrm{y}} \mathrm{l} \mathrm{cwt} / \mathrm{acre}=112.085 \mathrm{l} \mathrm{kg} \cdot \mathrm{ha}^{-1}$.

${ }^{x} 1$ inch $=2.54 \mathrm{~cm}$.

wiameter of multiple center $<1^{1 / 2}$ inches.

${ }^{\mathrm{v}} 0=$ no symptoms, $1=1 \%$ to $25 \%$ of foliage diseased, $2=26 \%$ to $50 \%$ of foliage diseased, $3=51 \%$ to $75 \%$ of foliage diseased, $4=76 \%$ to $99 \%$ of foliage diseased, $5=100 \%$ of foliage diseased.

uTukey's honest significant difference test.

were separated according to quality: bulbs without blemishes (No. 1s), split bulbs (No. 2s), and rotten bulbs. The No. 1 bulbs were graded according to diameter: small ( $<21 / 4$ inches), medium $\left(2^{1 / 4}-3\right.$ inches), jumbo (3-4 inches), colossal (4-41/4 inches), and super colossal (>41/4 inches). Bulb counts per $50 \mathrm{lb}$ of super colossal onions were determined for each plot by weighing and counting all super colossal bulbs during grading.

The data were analyzed using analysis of variance (General Linear Models procedure; Number Cruncher Statistical System, Kaysville, UT). Variety means were compared using Tukey's honest significant difference test at the $5 \%$ probability level. Correlations of IYSV symptom severity rating against onion yield were done using the Correlation Matrix procedure (Number Cruncher Statistical System). Only varieties with a maturity rating lower than $50 \%$ were included in the correlations. For varieties with maturity ratings higher than $50 \%$, the IYSV ratings could be inaccurate because of the difficulty of discerning between leaf senescence because of maturity and disease symptoms. For the correlations, each data point was the average yield and average virus rating for each variety.

\section{Results}

Visual observations of thrips feeding damage to onion leaves suggested that thrips pressure increased from 2004 to 2006 in the trials. 'Vaquero', which has been the most widely planted onion variety in the Treasure Valley, showed a reduction in yield in the trials at the Malheur Experiment Station over the years (Table 1). This yield reduction might be partly explained by the increasing severity of the virus starting in 2004 . The severity of IYSV symptoms increased from 2004 to 2006 (Tables 2 , 3 and 4). In 2004, IYSV symptoms were slight, symptom differences between varieties were small, and there was only a significant association of IYSV rating with colossal onion yield (Table 5). In 2005 and 2006, there were more pronounced differences between varieties in virus symptom severity. In 2005 and 2006, 
Table 4. Bulb yield, single center rating, and iris yellow spot virus (IYSV) rating for onion varieties evaluated in 2006. Varieties are ranked by IYSV rating.

\begin{tabular}{|c|c|c|c|c|c|c|c|c|}
\hline \multirow[b]{3}{*}{ Variety } & \multirow[b]{3}{*}{ Source ${ }^{\mathrm{z}}$} & \multicolumn{4}{|c|}{ Marketable yield by bulb diameter $(\mathrm{cwt} / \mathrm{acre})^{\mathrm{y}}$} & \multirow{3}{*}{$\begin{array}{c}\text { Single } \\
\text { centered }\end{array}$} & \multirow{3}{*}{$\begin{array}{c}\text { Functional } \\
\text { single center }\end{array}$} & \multirow{3}{*}{$\begin{array}{l}\text { IYSV rating } \\
(0-5 \text { scale })^{\mathrm{v}}\end{array}$} \\
\hline & & \multirow{2}{*}{$\begin{array}{c}\text { Total } \\
>21 / 4 \\
\text { inches }^{x}\end{array}$} & \multirow{2}{*}{$\begin{array}{c}\text { Super colossal } \\
>4^{1 / 4} \\
\text { inches } \\
\end{array}$} & \multirow{2}{*}{$\begin{array}{c}\text { Colossal } \\
4 \text { to } 4^{1 / 4} \\
\text { inches } \\
\end{array}$} & \multirow{2}{*}{$\begin{array}{l}\text { Jumbo } \\
3 \text { to } 4 \\
\text { inches } \\
\end{array}$} & & & \\
\hline & & & & & & & & \\
\hline OLYS05N5 & Crookham & 664.0 & 7.6 & 166.9 & 466.8 & 48.7 & 73.3 & 1.6 \\
\hline Joaquin & Nunhems & 713.5 & 16.2 & 184.2 & 496.7 & 63.3 & 84.0 & 1.6 \\
\hline Affirmed & Seminis & 632.2 & 1.8 & 105.1 & 500.6 & 44.7 & 71.3 & 1.8 \\
\hline Charismatic & Seminis & 669.6 & 10.4 & 177.6 & 450.7 & 24.7 & 55.3 & 1.9 \\
\hline Tequila & D. Palmer & 645.3 & 27.6 & 170.7 & 423.3 & 32.7 & 54.7 & 2.0 \\
\hline Evolution & D. Palmer & 639.2 & 16.2 & 169.6 & 437.9 & 70.0 & 87.3 & 2.1 \\
\hline Monarchos & Seminis & 596.8 & 0.0 & 45.4 & 524.7 & 58.7 & 88.0 & 2.2 \\
\hline Granero & Nunhems & 632.3 & 0.0 & 49.3 & 554.5 & 48.7 & 72.0 & 2.3 \\
\hline $\mathrm{XON}-450 \mathrm{Y}$ & Sakata & 624.4 & 12.6 & 142.7 & 439.7 & 24.0 & 50.0 & 2.3 \\
\hline EX5819 & Seminis & 681.0 & 7.4 & 86.7 & 554.3 & 33.3 & 61.3 & 2.3 \\
\hline $\mathrm{T}-433$ & A. Takii & 550.1 & 1.8 & 120.7 & 408.8 & 8.0 & 30.4 & 2.5 \\
\hline Sweet Perfection & Crookham & 572.9 & 13.9 & 145.0 & 395.1 & 32.0 & 52.7 & 2.5 \\
\hline Mesquite & D. Palmer & 622.5 & 10.9 & 139.5 & 445.6 & 13.3 & 42.0 & 2.5 \\
\hline Pandero & Nunhems & 575.2 & 3.2 & 48.7 & 483.8 & 36.0 & 60.0 & 2.5 \\
\hline Harmony & Crookham & 671.3 & 14.6 & 141.6 & 493.5 & 60.0 & 74.7 & 2.6 \\
\hline Ringleader & Global Gen. & 543.4 & 1.5 & 64.6 & 454.7 & 78.7 & 92.0 & 2.6 \\
\hline Maverick & Global Gen. & 578.6 & 3.9 & 116.3 & 439.3 & 32.7 & 60.7 & 2.7 \\
\hline Ranchero & Nunhems & 631.0 & 1.8 & 110.6 & 489.4 & 46.0 & 74.0 & 2.7 \\
\hline Sedona & Bejo & 481.2 & 0.0 & 3.9 & 433.0 & 19.3 & 48.7 & 2.8 \\
\hline Varsity & Global Gen. & 485.6 & 0.0 & 10.6 & 426.8 & 50.7 & 81.3 & 2.8 \\
\hline $9003 \mathrm{G}$ & A. Takii & 510.0 & 0.0 & 4.2 & 445.3 & 20.0 & 50.0 & 2.9 \\
\hline Vaquero & Nunhems & 595.4 & 2.1 & 52.3 & 509.3 & 60.7 & 78.0 & 2.9 \\
\hline Calibra & Bejo & 462.8 & 0.0 & 0.0 & 377.6 & 33.2 & 61.9 & 3.0 \\
\hline Montero & Nunhems & 506.4 & 0.0 & 17.5 & 431.3 & 63.3 & 86.0 & 3.0 \\
\hline Sabroso & Nunhems & 477.3 & 0.0 & 0.0 & 395.0 & 58.0 & 87.3 & 3.2 \\
\hline Crocket & Bejo & 411.3 & 0.0 & 2.5 & 323.2 & 8.7 & 36.7 & 3.4 \\
\hline Talon & Bejo & 353.6 & 0.0 & 1.7 & 225.2 & 42.0 & 70.0 & 3.4 \\
\hline 6093 & Global Gen. & 532.1 & 0.0 & 20.5 & 472.8 & 66.7 & 86.0 & 3.5 \\
\hline Arcero & Nunhems & 588.6 & 0.0 & 39.9 & 514.7 & 77.3 & 91.3 & 3.5 \\
\hline Koala & Zetaseeds & 484.6 & 0.0 & 22.6 & 417.3 & 76.4 & 90.6 & 3.5 \\
\hline Solid Gold & Rispens & 245.6 & 0.0 & 0.0 & 106.4 & 20.7 & 52.0 & 3.8 \\
\hline Grand Coulee & Nunhems & 390.1 & 0.0 & 1.6 & 272.3 & 77.3 & 95.3 & 3.9 \\
\hline Generation X & D. Palmer & 426.4 & 0.0 & 3.3 & 371.3 & 89.3 & 97.3 & 4.1 \\
\hline Average & & 551.3 & 4.6 & 71.7 & 429.7 & 46.0 & 69.6 & 2.7 \\
\hline Critical values $^{\mathrm{u}}(0$ & & 116.8 & 11.4 & 56.3 & 112.2 & 19.7 & 17.8 & 0.6 \\
\hline
\end{tabular}

${ }^{\text {z} A m e r i c a n ~ T a k i i, ~ I n c ., ~ S a l i n a s, ~ C A ; ~ B e j o ~ S e e d s, ~ I n c ., ~ O c e a n o, ~ C A ; ~ C r o o k h a m ~ C o ., ~ C a l d w e l l ~ I D ; ~ D . ~ P a l m e r ~ S e e d ~ C o ., ~ Y u m a, ~ A Z ; ~ G l o b a l ~ G e n e t i c s, ~ P a y e t t e, ~ I D, ~ R i s p e n s ~ S e e d s, ~}$ Inc., Beecher, IL; Seminis, Inc., Oxnard, CA; Nunhems, Parma, ID.

${ }^{\mathrm{y}} \mathrm{l} \mathrm{cwt} / \mathrm{acre}=112.0851 \mathrm{~kg} \cdot \mathrm{ha}^{-1}$

${ }^{x} 1$ inch $=2.54 \mathrm{~cm}$.

"Diameter of multiple center $<1-1 / 2$ inches.

${ }^{\mathrm{v}} 0=$ no symptoms, $1=1 \%$ to $25 \%$ of foliage diseased, $2=26 \%$ to $50 \%$ of foliage diseased, $3=51 \%$ to $75 \%$ of foliage diseased, $4=76 \%$ to $99 \%$ of foliage diseased, $5=100 \%$ of foliage diseased.

"Fisher's least significant difference test for all except virus IYSV rating. For IYSV rating, Tukey’s honest significant difference test.

Table 5. Spearman rank correlation coefficient and significance level between average iris yellow spot virus (IYSV) symptoms and onion yield by diameter category.

\begin{tabular}{|c|c|c|c|c|c|c|c|c|}
\hline \multirow[b]{2}{*}{ Year } & \multicolumn{2}{|c|}{$\begin{array}{c}\text { Marketable yield } \\
>2^{1 / 4} \text { inches }^{\mathrm{z}}\end{array}$} & \multicolumn{2}{|c|}{$\begin{array}{c}\text { Super colossal } \\
>4^{1 / 4} \text { inches }\end{array}$} & \multicolumn{2}{|c|}{$\begin{array}{c}\text { Colossal } \\
4 \text { to } 4^{1 / 4} \text { inches }\end{array}$} & \multicolumn{2}{|c|}{$\begin{array}{c}\text { Jumbo } \\
3 \text { to } 4 \text { inches }\end{array}$} \\
\hline & $\mathbf{r}$ & $P$ & $\mathbf{r}$ & $P$ & $\mathbf{r}$ & $P$ & $\mathbf{r}$ & $P$ \\
\hline 2005 & -0.85 & 0.001 & -0.66 & 0.001 & -0.87 & 0.001 & -0.78 & 0.001 \\
\hline 2006 & -0.83 & 0.001 & -0.69 & 0.001 & -0.80 & 0.001 & -0.50 & 0.01 \\
\hline
\end{tabular}

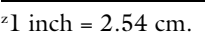

onion marketable, super colossal, colossal, and jumbo yield decreased with increasing IYSV symptom severity among varieties (Table 5 ).
Average onion marketable yield was substantially lower in 2005 and 2006 than in 2004, and was associated with a greater severity of IYSV in 2005 and
2006 and possibly other weatherrelated factors. Excessive precipitation in Fall 2004 and Spring 2005 prevented field operations from being 
conducted in a timely manner in 2005. In 2006, cool weather until the start of bulbing reduced foliage growth. Our results, showing a negative correlation between bulb yield and virus symptoms, are in agreement with the observations of du Toit and Pelter (2004) and Gent et al. (2004).

In 2005 and 2006, onion bulb size decreased with increasing IYSV symptom severity among varieties (Table 5). Average yield of colossal and super colossal bulbs was substantially lower in 2005 and 2006 than in 2004 , and was associated with a greater severity of IYSV in 2005 and 2006 (Tables 2, 3, 4, and 5).

Each year some varieties had a combination of high yield, large bulb size, and a high proportion of singlecentered bulbs. In 2004, 'Granero', 'Vaquero', 'EX5819', '6011', and 'Arcero' had more than $400 \mathrm{cwt} / \mathrm{acre}$ colossal yield and more than $80 \%$ functionally single-centered bulbs. In 2005, 'Joaquin', 'Maverick', and '6011' had more than $100 \mathrm{cwt} /$ acre colossal yield and more than $80 \%$ functionally single-centered bulbs. In 2006, 'Joaquin' and 'Evolution' had more than $100 \mathrm{cwt} /$ acre colossal yield and more than $80 \%$ functionally singlecentered bulbs. 'Joaquin' had among the lowest IYSV ratings in 2005. 'Joaquin' and 'Evolution' had among the lowest IYSV ratings in 2006.

The variety trials at Ontario from 2004 to 2006 suggest that IYSV has become a major limiting factor in onion productivity in the Treasure Valley. The decline in onion yield at the Malheur Experiment Station parallels the decline in onion yield in the Treasure Valley. Average onion yield in the Treasure Valley was 775,640 , and $530 \mathrm{cwt} /$ acre in 2004, 2005, and 2006, respectively (U.S. Department of Agriculture, 2007). This reduction in onion yield in the Treasure Valley equates to a $32 \%$ yield loss between 2004 and 2006. Onion yield and bulb size responses to IYSV are partly variety dependent. To the extent that the trials suffer from heavy virus pressure, evaluations of variety performance under these conditions can aid breeders and growers in selecting varieties with some level of tolerance or resistance, or at least less susceptibility. The results of these trials are preliminary because thrips variety preference can be a confounding factor in evaluating variety response to IYSV.

\section{Literature cited}

Allen, J.K.M., C.D. Scott-Dupree, J.H. Tolman, and C.R. Harris. 2005. Resistance of Thrips tabaci to pyrethroid and organophosphate insecticides in Ontario, Canada. Pest Mgt. Sci. 61:809-815.

Cramer, C.S. 2006. Onion trait heritability and response from selection. J. Amer. Soc. Hort. Sci. 131:646-650.

Du Toit, L.J. and G.Q. Pelter. 2004. Susceptibility of storage onion varieties to iris yellow spot in the Columbia Basin of Washington, 2004. Biol. Cult. Tests 20:V006.

Gamie, A.A., F.A. Ahmed, A.K.I. ElKafury, and G.H. Abd El-Rehim. 1995. Suitability of $S_{3}$ progeny of single center Shandaweel 1 onion for bulb production from sets at Sohag. Assiut J. Agr. Sci. 26(2):73-80.

Gent, D.H., H.F. Schwartz, and R. Khosla. 2004. Distribution and incidence of iris yellow spot virus in Colorado and its relation to onion plant population and yield. Plant Dis. 88:446-452.

Gent, D.H., L.J. du Toit, S.F. Fichtner, S.K. Mohan, H.R. Pappu, and H.F. Schwartz. 2006. Iris yellow spot virus: An emerging threat to onion bulb and seed production. Plant Dis. 90:14681480 .

Kritzman, A., M. Lampel, B. Raccah, and A. Gera. 2001. Distribution and transmission of iris yellow spot virus. Plant Dis. 85:838-842.

McGrath, D., J. Rinehold, and C.S. Hollingsworth. 2007. Onion, p. 313-316. In: C.S. Hollingsworth (ed.). Pacific Northwest insect management handbook. Oregon State Univ. Ext. Sta. Commun., Corvallis.

Mohan, S.K. and J.W. Moyer. 2004. IYSV symptoms and etiology: Observations since 1989. 3 Mar. 2007. <http:// www.colostate.edu/Depts/CoopExt/ TRA/Allium/abstract.html>

Nagata, T. and A.C.L. Almeida. 1999. The identification of the vector species of iris yellow spot tospovirus occurring on onion in Brazil. Plant Dis. 83: 399. (Abstr.).

Peachey, E. 2007. Onions, p. 300-303. In: E. Peachy, D. Ball, R. Parker, J.P. Yenish, T.W. Miller, D.W. Morishita, and P.J.S. Hutchinson (eds.). Pacific Northwest weed management handbook. Oregon State Univ. Ext. Sta. Commun., Corvallis.

Shock, C.C. 2003. Soil water potential measurement by granular matrix sensors, p 899-903. In: B.A. Stewart, and T.A. Howell (eds.). The Encyclopedia of Water Science. Marcel Dekker, New York.

Shock, C.C., A. Corn, S. Jedehdu, L. Jensen, and C.A. Shock. 2002. Evaluation of the AM 406 soil moisture datalogger to aid irrigation scheduling. Oregon State Univ. Agr. Expt. Sta. Spec. Rpt. 1038: 252-261.

Shock, C.C., E.B.G. Feibert, and L.D. Saunders. 1998. Onion yield and quality affected by soil water potential as irrigation threshold. HortScience 33:11881191.

Shock, C.C., E.B.G. Feibert, and L.D. Saunders. 2005a. Single-centered and super colossal bulbs from yellow onion varieties. HortTechnology 15:399-408.

Shock, C.C., R. Flock, E. Feibert, C.A. Shock, A. Pereira, and L. Jensen. 2005b. Irrigation monitoring using soil water tension. Oregon State Univ. Ext. Serv. EM 8900.

Shock, C.C., J.K. Ishida, E.P. Eldredge, and M. Seddigh. 2000. Yield of yellow onion varieties in eastern Oregon and south western Idaho. HortTechnology 10(3):613-620.

Sullivan, D.M., B.D. Brown, C.C. Shock, D.A. Horneck, R.G. Stevens, G.Q. Pelter, and E.B.G. Feibert. 2001. Nutrient management for onions in the Pacific Northwest. Pacific Northwest Ext. Publ. 546.

U.S. Department of Agriculture. 2007. Vegetables 2006 summary, Natl. Agr. Stat. Serv. Vg 1-2 (07) p. 24-26. 3 Mar. 2007. http://www.nass.usda.gov/Publications/Todays_Reports/reports / vgan0107.pdf>

Wall, M.M., A. Mohammad, and J.N. Corgan. 1996. Heritability estimates and response to selection for the pungency and single center traits in onion. Euphytica 87:133-139. 